\title{
Conference of Social Scientists on the Social Effects of Industrialization in Africa
}

A study conference is to be held at Abidjan, French West Africa, in September-October 1954 under the auspices of UNESCO at which papers on various aspects of industrialization and urbanization in Africa will be presented and discussed. The participants will be some ten or twelve social scientists who have cartied out field studies concerned with this topic, and observers from various governments and research organizations have been invited to attend. Professor Daryll Forde, Director of the International African Institute, is responsible for organizing the Conference and the Survey of recent and current feld studies on the social effects of economic development in Africa, prepared for UNESCO by the Institute, as well as the report of the team who recently completed a survey in Stanleyville (see Africa, xxiii. 4, p. 347, and Report of the Administrative Director, p. 265 above) will be used as working papers for the Conference.

Since the purpose of the Conference is to promote comparative study through an exchange of views on current research methods and findings, it will not pass resolutions or draw up recommendations outside the research field. A report of the Conference, based on the papers presented and the views developed in the discussions, will be published by UNESCO.

\section{Inter-African Soils Conference}

An Inter-African Soils Conference will be held in Leopoldville (Belgian Congo) from 9-15 August 1954 at the invitation of the Belgian Government and under the auspices of C.C.T.A. Every member country of C.C.T.A. is invited to send as delegates a maximum of eighty experts on agronomy, soil science, and soil conservation; invitations have also been sent to organizations likely to be interested in the Conference. The work of the Conference will be divided into three sections, concerned respectively with: classification and mapping of African soils; soil research of all kinds; soil conservation.

The Vth International Congress of Soil Science will take place in Leopoldville immediately after this Conference. The technical secretariat of the soils conference is the B.I.S. (Inter-African Bureau for Soils), 57 rue Cuvier, Paris Ve, to which requests for information should be addressed.

\section{Inter-African Conference on Rural Welfare}

A Conference on Rural Welfare was held in Lourenço Marques in September 1953 under the auspices of the Commission for Technical Co-operation in Africa South of the Sahara (C.C.T.A.). The Conference, which was opened by the Governor-General of Mozambique, was attended by delegates from Belgium, France, the United Kingdom, Portugal, Union of South Africa, Gold Coast, Kenya, Tanganyika, Rhodesia, Uganda, Basutoland, and Swaziland. The Chairman of the Conference was Professor Alvaro Eugenio Neves da Fontoura, of the Escola Superior Colonial, Lisbon. The delegates submitted reports on the two main topics with which the Conference was concerned: (I) social structure, which included population problems, family structure, status of women, housing, nutrition, medical services, communications and transport; (2) economic factors, including land tenure, agricultural practice, development of local resources, credit and mutual aid societies, co-operatives.

These reports were considered by a 'steering' Committee which agreed upon a basis on which the Conference could discuss the general objectives of the policy of rural development and the means of attaining those objectives. The Conference then divided into three commissions for the detailed discussion of topics grouped under Social Structure, Economic 